\title{
Classll peroxidase-encoding genes are present in a phylogenetically wide range of ectomycorrhizal fungi
}

\author{
Inga TM Bödeker ${ }^{1}$, Cajsa MR Nygren ${ }^{1}$, Andy FS Taylor ${ }^{2}$, Åke Olson ${ }^{1}$ and \\ Björn D Lindahl ${ }^{1}$ \\ ${ }^{1}$ Department of Forest Mycology and Pathology, Swedish University of Agricultural Sciences, Uppsala, \\ Sweden and ${ }^{2}$ The Macaulay Land Use Research Institute, Craigiebuckler, Aberdeen, UK
}

\begin{abstract}
Fungal peroxidases (ClassII) have a key role in degrading recalcitrant polyphenolic compounds in boreal forest wood, litter and humus. To date, their occurrence and activity have mainly been studied in a small number of white-rot wood decomposers. However, peroxidase activity is commonly measured in boreal forest humus and mineral soils, in which ectomycorrhizal fungi predominate. Here, we used degenerate PCR primers to investigate whether peroxidase-encoding genes are present in the genomes of a wide phylogenetic range of ectomycorrhizal taxa. Cloning and sequencing of PCR products showed that ectomycorrhizal fungi from several different genera possess peroxidase genes. The new sequences represent four major homobasidiomycete lineages, but the majority is derived from Cortinarius, Russula and Lactarius. These genera are ecologically important, but consist mainly of non-culturable species from which little ecophysiological information is available. The amplified sequences contain conserved active sites, both for folding and substrate oxidation. In some Cortinarius spp., there is evidence for gene duplications during the evolution of the genus. Classll peroxidases seem to be an ancient and a common feature of most homobasidiomycetes, including ectomycorrhizal fungi. Production of extracellular peroxidases may provide ectomycorrhizal fungi with access to nitrogen sequestered in complex polyphenolic sources.
\end{abstract}

The ISME Journal (2009) 3, 1387-1395; doi:10.1038/ismej.2009.77; published online 2 July 2009

Subject Category: microbial ecosystem impacts

Keywords: Classll peroxidases; decomposition; degenerate primer; ectomycorrhiza; nutrient cycling; soil organic matter

\section{Introduction}

In the low productive soils of boreal forest ecosystems, large amounts of carbon (C) are incorporated into polyphenolic compounds. The high content of phenolic secondary metabolites, such as lignin and tannins, in the plant litter leads to slow decomposition (Aerts, 1995). On account of the low turnover rates, carbon accumulates in humus layers and soils, making the boreal forest biome a global sink for carbon (Myneni et al., 2001).

During decomposition of plant litter, access to hydrolysable compounds, such as cellulose, progressively decreases, as an increasing fraction is

Correspondence: ITM Bödeker, Department of Forest Mycology and Pathology, Swedish University of Agricultural Sciences, SLU, Box 7026, Ullsväg 26A, Uppsala SE 750 07, Sweden.

E-mail: inga.bodeker@mykopat.slu.se

Received 20 April 2009; revised 28 May 2009; accepted 2 June 2009; published online 2 July 2009 locked up in recalcitrant complexes with lignin and other polyphenols. Nutrients, such as nitrogen $(\mathrm{N})$ and phosphorus, also become immobilized in polyphenolic humus complexes. This process contributes to the low nutrient availability in boreal forests, which limits productivity of the ecosystem (Northup et al., 1995). Enzymatic degradation of polyphenolic complexes is mainly carried out by oxidative enzymes, such as laccases and peroxidases (Bao et al., 1993; Passardi et al., 2007a). Both enzymes have a central role in wood decomposition (Rayner et al., 1987), but peroxidases have higher redox potentials than laccases (Baldrian, 2006). Lignified plant cell walls appeared during the midPaleozoic era, but enzyme systems with a high capacity to degrade polyphenolic organic matter may not have appeared until the late Paleozoic (Robinson, 1996). The delayed evolution of fungal lignin-degrading enzymes has been proposed as an explanation to the global-scale accumulation of organic matter and reduced atmospheric $\mathrm{CO}_{2}$ 
concentrations that occurred during this period (Robinson, 1996).

ClassII peroxidases belong to the heme peroxidases and are known to be secreted by several homobasidiomycetes (Hatakka, 1994). They have traditionally been divided into lignin peroxidases (LiP; EC 1.11.1.14) and manganese peroxidases (MnP; EC 1.11.1.13) (Rayner et al., 1987). By reducing $\mathrm{H}_{2} \mathrm{O}_{2}$, peroxidases obtain a high redox potential and are thereby able to oxidize a wide range of substrates. Lignin degradation by $\mathrm{LiP}$ is mediated by the oxidation of aromatic substrates (Pérez-Boada et al., 2005). Manganese peroxidases oxidize Mn(II) to Mn(III), which becomes chelated with oxalic acid or other organic acids. The chelate reacts with polyphenolic substrates, which are oxidized and degraded. A third group of fungal peroxidases has been termed versatile peroxidases (VP; EC 1.11.1.16) and combines the catalytic properties of both LiPs and MnPs (Hatakka, 1994; Martinez, 2002; Passardi et al., 2007a).

Fungal peroxidases have been studied almost exclusively within the context of wood decomposition, with research primarily aimed at industrial applications. However, peroxidase activity is frequently measured in litter and soils, as an indicator of decomposition of recalcitrant organic matter (Sinsabaugh, 2005). Manganese peroxidases have been suggested to be involved in the degradation of humic compounds (Steffen et al., 2002). Detailed descriptions of the enzymes are restricted to a narrow phylogenetic range of polyporoid wood decomposers (for example, Phanerochaete chrysosporium, Trametes versicolor and Phlebia radiata) and Pleurotus spp. (Hatakka, 1994; Martinez, 2002) There is a clear need for further investigations into peroxidases from other ecological and phylogenetic groups of fungi, as previously pointed out by Kirk and Farrell (1987). In the humus and soils of boreal forests, the fungal community is dominated by ectomycorrhizal fungi (Lindahl et al., 2007), which possibly act as decomposers (Talbot et al., 2008).

Ectomycorrhizal fungi have evolved repeatedly from saprotrophic ancestors at several independent occasions (Hibbett et al., 2000). Free-living decomposers and ectomycorrhizal fungi may, thus, be more functionally similar than considered previously, and ectomycorrhizal fungi may have retained many enzymes involved in organic matter degradation (Koide et al., 2008). Several studies have shown degradative abilities of ectomycorrhizal fungi, and it has been proposed that the utilization of complex organic compounds by these fungi might have a fundamental role in the nutrient cycles of boreal forests (Read, 1991; Lindahl et al., 2002). Some ectomycorrhizal fungi have been shown to produce peroxidase activity in pure culture (Bending and Read, 1997) and to release ${ }^{14} \mathrm{C}$ from labeled aromatic complexes such as lignin, lignocellulose and coniferyl alcohol (Trojanowski et al., 1984;
Haselwandter et al., 1990). Chambers et al. (1999) recovered a 260-bp ClassII peroxidase-encoding sequence fragment from the ectomycorrhizal fungus Tylospora fibrillosa, and also measured enzymatic activity. Recent results (Martin et al., 2008) showed that a ClassII peroxidase-encoding gene is present in the genome of the ectomycorrhizal fungus Laccaria bicolor, suggesting that peroxidase genes may also be present in other ectomycorrhizal fungi.

To obtain gene sequences for fungal peroxidases, degenerate primers have been used to target limited functional and phylogenetic groups of taxa (Maijala et al., 2003; Morgenstern et al., 2008). This approach has also been used to screen for other enzymeencoding genes in a phylogenetically wider range of ectomycorrhizal fungi (Lindahl and Taylor, 2004; Nygren et al., 2008).

The aim of this study was to investigate the occurrence of ClassII peroxidase-encoding genes across a broad phylogenetic range of ectomycorrhizal taxa within the homobasidiomycetes. We developed degenerate PCR primers with low specificity and screened PCR products for peroxidase gene sequences by cloning, sequencing and database comparisons.

\section{Materials and methods}

Design of degenerate PCR primers

Amino-acid sequences and their corresponding nucleotide sequences of published ClassII peroxidases were collected from PeroxiBase (Passardi et al., 2007b) and National Center for Biotechnology Information (NCBI) databases. In addition, the published genomes of the basidiomycetes L. bicolor, P. chrysosporium, Postia placenta, Sporobolomyces roseus (http://www.jgi.doe.gov) and Coprinopsis cinerea, Cryptococcus neoformans, Puccinia graminis, Ustilago maydis (http://www.broad.mit.edu) were screened for ClassII peroxidase-encoding genes, using the BlastN algorithm (Altschul et al., 1997). A multiple alignment of all retrieved protein sequences was conducted, using the ClustalW algorithm in MegAlign (DNAStar Inc., Madison, WI, USA) and adjusted manually.

The alignment was used to identify conserved homologous regions in the protein sequences across a broad range of isoenzymes and phylogenetic lineages. The sites chosen as targets for degenerate primers were a Ca-binding site (GGADGS) for the forward primer and a Ca- and heme-binding site (PFDSTP) for the reverse primer (Martinez, 2002). Primers targeting the same sites have previously been used to amplify peroxidase genes from the wood-decaying russuloid fungi Heterobasidion spp. (Maijala et al., 2003). In this study, more degenerate primers were constructed to cover a broader range of different ClassII peroxidases.

The primers were designed based on the nucleotide sequences to cover all variation present in 
currently sequenced ClassII peroxidases from basidiomycetes, except the lignin peroxidases from the polyporoid clade (clade F in Figure 3 in Morgenstern et al., 2008) and the MnPs from P. chrysosporium and related taxa (clade A in Figure 3 in Morgenstern et al., 2008). The latter group was excluded because of an intron, situated within the reverse primer site. The primer sequences were Primer 1 (forward) $5^{\prime}$-GGIGGIGCIGAYGGITC- $3^{\prime}$ and Primer 2 (reverse) $5^{\prime}$-GGIGTIGARTCGAABGG-3').

\section{PCR, cloning and sequencing}

DNA was extracted from dried fruit bodies, cultured material, and fresh, whole sporocarps from a broad range of ectomycorrhizal fungi and from a small number of wood decomposers. We investigated the following species: Amanita muscaria, A. pantherina, A. porphyria, A. vaginata, Boletus edulis, Chalciporus piperatus, Chroogomphus rutilans, Clavariadelphus ligula, Cortinarius armillatus, $C$. croceconus, C. croceus, C. delibutus, C. elegantior, $C$. hinnuleus, C. infractus, C. limonius, C. malachius, C. malicorius, C. traganus, $C$. triumphans, $C$. variicolor, Coltricia perennis, Craterellus tubaeformis, Gomphidius maculatus, Gomphus clavatus, Hebeloma cf. crustuliniforme, $H$. mesophaeum, $H$. cf. mesophaeum, $H$. cf. sacchariolens, $H$. sinapizans, Hydnellum peckii, Hygrophorus agathosmus, $H$. erubescens, H. hypothejus, H. personii, Hypholoma fasciculare, Inocybe geophylla var. lilacina, Laccaria amethystina, Lactarius mammosus, $L$. fulvissimus, L. queticolor, L. rufus, L. scrobiculatus, Leccinium versipelle, Limacella glioderma, Marasmius androsaceus, Mycena epipterygia, Paxillus involutus, Phellinus ferrugineofuscus, Piloderma byssinum, $P$. croceum, $P$. olivaceum, $P$. sphaerosporum, Pisolithus tinctorius, Russula aurea, R. badia, $R$. caerulea, $R$. foetens, $R$. cf. postiana, $R$. sanguinea, $R$. sardonia, $R$. xerampelina, Sarcodon imbricatum, Sarcodon sp, Sclerogaster compactus, Suillus grevillei, S. variegatus, Thelephora palmata, Tricholoma focale, T. fracticum, T. fulvum, T. scalpturatum, T. terreum, Uloporus lividus, Xerocomus badius and X. communis (for details, see Supplementary material).

Fungal material was homogenized together with glass beads ( $3 \mathrm{~mm}$ diameter) in $1.5 \mathrm{ml}$ tubes, using a Fast Prep shaker (Precellys 24, Bertin Technologies, Montigny-le-Bretonneux, France) for $30 \mathrm{~s}$ at a frequency of 5000 r.p.m. Homogenization was repeated after the addition of $1 \mathrm{ml}$ of $3 \%(\mathrm{w} / \mathrm{v})$ hexadecyltrimethyl-ammonium bromide buffer, $2.5 \mathrm{M} \mathrm{NaCl}$, $0.15 \mathrm{M}$ Tris and $2 \mathrm{mM}$ EDTA, and the samples were incubated at $65^{\circ} \mathrm{C}$ for $1 \mathrm{~h}$. After centrifugation, the supernatant was extracted once with chloroform. The DNA was precipitated with 1.5 volumes of isopropanol at minus $20{ }^{\circ} \mathrm{C}$ (overnight) and the pellet was washed with $70 \%$ ice-cold ethanol and re-suspended in water. In cases where whole, fresh sporocarps were used, the fungal material was first ground in liquid nitrogen before being mixed with the buffer.
PCR was conducted in reactions containing $4 \mu \mathrm{M}$ of each of the degenerate PCR primers, 20-40 ng genomic DNA, 0.2 mM dNTPs (Fermentas, Burlington, Canada), $0.75 \mathrm{mM} \mathrm{MgCl}_{2}$ and $0.1 \mathrm{U}$ of DNApolymerase RedTaq (ThermoRed, Saveen \& Werner AB, Limhamn, Sweden) in a total reaction volume of $10 \mu \mathrm{l}$. The cycling conditions included an initial denaturation at $94{ }^{\circ} \mathrm{C}$ for $95 \mathrm{~s}$ and 34 cycles of $94{ }^{\circ} \mathrm{C}$ denaturation for $35 \mathrm{~s}$, annealing for $1 \mathrm{~min}$ and elongation at $72{ }^{\circ} \mathrm{C}$ for $2 \mathrm{~min}$. Annealing temperature was optimized by running gradient PCRs with temperatures ranging from 47 to $60^{\circ} \mathrm{C}$ on DNA from a selected subset of taxa. The optimum temperature varied between 52 and $57^{\circ} \mathrm{C}$. Therefore, all samples were subjected to separate PCRs at three different annealing temperatures (52, 55 and $57^{\circ} \mathrm{C}$ ). After visualization of PCR products on agarose gels (1\%), samples containing PCR products between 350 and $700 \mathrm{bp}$ were selected for cloning. These products were ligated into the pCR2.1-TOPO vector (Invitrogen, Carlsbad, CA, USA) according to the manufacturer's instructions, but with reactions scaled down to half the volume. The vector was then transformed into OneShot TOP10 (Invitrogen) chemically competent Escherichia coli cells. At least eight clones per sample were chosen for subsequent colony PCR (0.2 mM dNTPs (Fermentas), $0.75 \mathrm{mM}$ $\mathrm{MgCl}_{2}, 0.2 \mathrm{mM}$ dNTPs (Fermentas), 1.25 U of DNApolymerase RedTaq (ThermoRed, Saveen \& Werner AB)), using $0.25 \mu \mathrm{M}$ of the primers M13 Forward (5'-GTA AAA CGA CGG TAG-3') and M13 Reverse (5'-GGA AAC AGC TAT GAC CAT-3'). The PCR cycle conditions consisted of an initial denaturation for $5 \mathrm{~min}$ at $94{ }^{\circ} \mathrm{C}$, then 35 cycles of $30 \mathrm{~s}$ at $94{ }^{\circ} \mathrm{C}$, $30 \mathrm{~s}$ at $55^{\circ} \mathrm{C}, 30 \mathrm{~s}$ at $72{ }^{\circ} \mathrm{C}$ and a final elongation step at $72{ }^{\circ} \mathrm{C}$ for $7 \mathrm{~min}$. PCR products of at least $500 \mathrm{bp}$ long were purified using the Agencourt AMPure kit (Agencourt Bioscience Corporation (Beckman Coulter), Beverly, MA, USA) and subsequently sequenced using a CEQ DTCS Quick Start Kit in the CEQ 8000 Genetic Analysis System (Beckman Coulter, Fullerton, CA, USA). Obtained sequences were proof-edited and assembled using SeqMan (DNAStar Inc.). After manual inspection, consensus sequences representing unique gene sequences were compared with protein sequences published on NCBI's non-redundant (nr) protein database, using the BlastX algorithm (Altschul et al., 1997). The sequences that were identified as ClassII peroxidases, according to $e$-values below $1^{-10}$ were translated into protein sequences, after manual removal of introns. The sequences are stored at NCBI under accession numbers: FJ754003-FJ754023. Protein sequences were aligned together with the published reference sequences using ClustalW (Chenna et al., 2003) in Megalign (DNAStar Inc.). The aligned sequences were trimmed by removing nonoverlapping parts, and relatedness was investigated by the neighbor-joining analysis, with mean character difference using PAUP* $4.0 \mathrm{~b} 10$ (Swofford, 2003). 


\section{Results and Discussion}

In total, we detected 21 novel peroxidase-encoding genes from 13 different species, representing four of the seven major homobasidiomycete clades (Table 1). Of the 21 genes, 9 were recovered from five Cortinarius species: four different genes in $C$. armillatus, two different genes in C. traganus, and one each in $C$. malachius, $C$. infractus and C. hinnuleus. Most of the Cortinarius sequences are similar to each other in amino-acid sequence (83-93\% identity) and receive a bootstrap support of 100 in the neighbour-joining analysis (Figure 1) to each other. C. infractus diverges from the others, with $62-69 \%$ sequence identity to the other Cortinarius species. The Cortinarius amplicons cluster together with two peroxidase sequences obtained from the agaric, white-rot wood decayer $H$. fasciculare (bootstrap 72). A third Hypholoma sequence groups together with the single peroxidase gene detected in the L. bicolor genome (bootstrap 99). The three Hypholoma sequences, the Laccaria gene and the Cortinarius amplicons form a non-supported clade. This group contains peroxidase genes of euagaric fungal taxa, including symbiotic ectomycorrhizal fungi as well as a potent white-rot wood decayer. Cortinarius species are notoriously difficult to cultivate. Therefore, physiological information is scarce from this widely distributed, commonly occurring and species-rich genus. However, a welldeveloped capacity to oxidize complex organic compounds fits well with predominant occurrence of Cortinarius species on acidic, low-productive soils rich in organic matter (Knudsen and Versterholt, 2008).

Single peroxidase-encoding genes were recovered from each of four ectomycorrhizal fungi within the family Russulaceae: Lactarius fulvissimus, L. rufus,
Russula sardonia and R. xerampelina. They group together with a bootstrap support of 99 (Figure 1). However, the Russula and Lactarius genes do not cluster with previously described peroxidase genes from wood-decaying Heterobasidion spp., which is also a member of the russuloid clade. This may indicate different evolutionary origins of the genes being paralogs, or that the taxa are simply too distantly related to cluster together in this phylogeny.

We recovered a single peroxidase amplicon from the ectomycorrhizal species $H$. agathosmus, which clusters among the versatile peroxidases of Pleurotus spp. The lack of bootstrap support makes the phylogenetic placement of this sequence highly uncertain.

A peroxidase-encoding sequence was also recovered from the ectomycorrhizal species G. clavatus, implying that ClassII peroxidases are present also within the gomphoid clade, which constitutes a separate clade within the homobasidiomycete phylogeny (Binder et al., 2005). The Gomphus sequence clusters (bootstrap 73) with the well-studied manganese peroxidases of $P$. chrysosporium (group A in Morgenstern et al., 2008). In the same group, two sequences obtained from $P$. ferrugineofuscus are found, one being closely related (bootstrap 98) to a sequence of Formitoporia mediterranea, which also belongs to the hymenochaetoid clade (Morgenstern et al., 2008). A third Phellinus sequence, in contrast, clusters together with the saprotrophic russuloid peroxidases, but with low bootstrap support (Figure 1).

Although PCR was conducted on 77 different homobasidiomycetes, peroxidase sequences were only amplified from 13 taxa. In the other taxa, either no PCR products were obtained or the sequenced amplicons did not show any homology

Table 1 Fungal species from which peroxidase sequences were successfully amplified

\begin{tabular}{|c|c|c|c|c|}
\hline Clade $^{\mathrm{a}}$ & Species & Sample ID/strain & $\begin{array}{c}\text { No. of detected } \\
\text { genes }\end{array}$ & Ecology \\
\hline \multirow[t]{7}{*}{ Euagaricoid } & Cortinarius armillatus (Fr.) Fr. & AT2004229 & 4 & ECM \\
\hline & Cortinarius traganus (Fr.) Fr. & AT2003082 & 2 & ECM \\
\hline & Cortinarius hinnuleus Fr. s. lato & AT2005088 & 1 & ECM \\
\hline & Cortinarius infractus Berk. & AT2004203 & 1 & ECM \\
\hline & Cortinarius malachius (Fr.) Fr. & AT2004075 & 1 & ECM \\
\hline & Hygrophorus agathosmus (Fr.) Fr. & CN0137 & 1 & ECM \\
\hline & Hypholoma fasciculare (Huds.) P. Kumm. & LH16 & 3 & WR \\
\hline \multirow[t]{4}{*}{ Russuloid } & Russula sardonia Cooke & CN0127 & 1 & ECM \\
\hline & Russula xerampelina (Schaeff.) Fr. s. str. & CN0159 & 1 & ECM \\
\hline & Lactarius fulvissimus Romagn. & CN0142 & 1 & ECM \\
\hline & Lactarius rufus (Scop.) Fr. & CN0131 & 1 & ECM \\
\hline Gomphoid & Gomphus clavatus (Pers.) Gray & AT2003099 & 1 & ECM \\
\hline Hymenochaetoid & Phellinus ferrugineofuscus (P. Karst.) Fias. and Niem. & Katrim 1101 & 3 & WR \\
\hline
\end{tabular}

Abbreviations: ECM, ectomycorrhizal (dried fruit body material), WR, wood rotting (in culture).

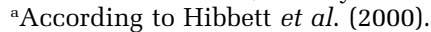




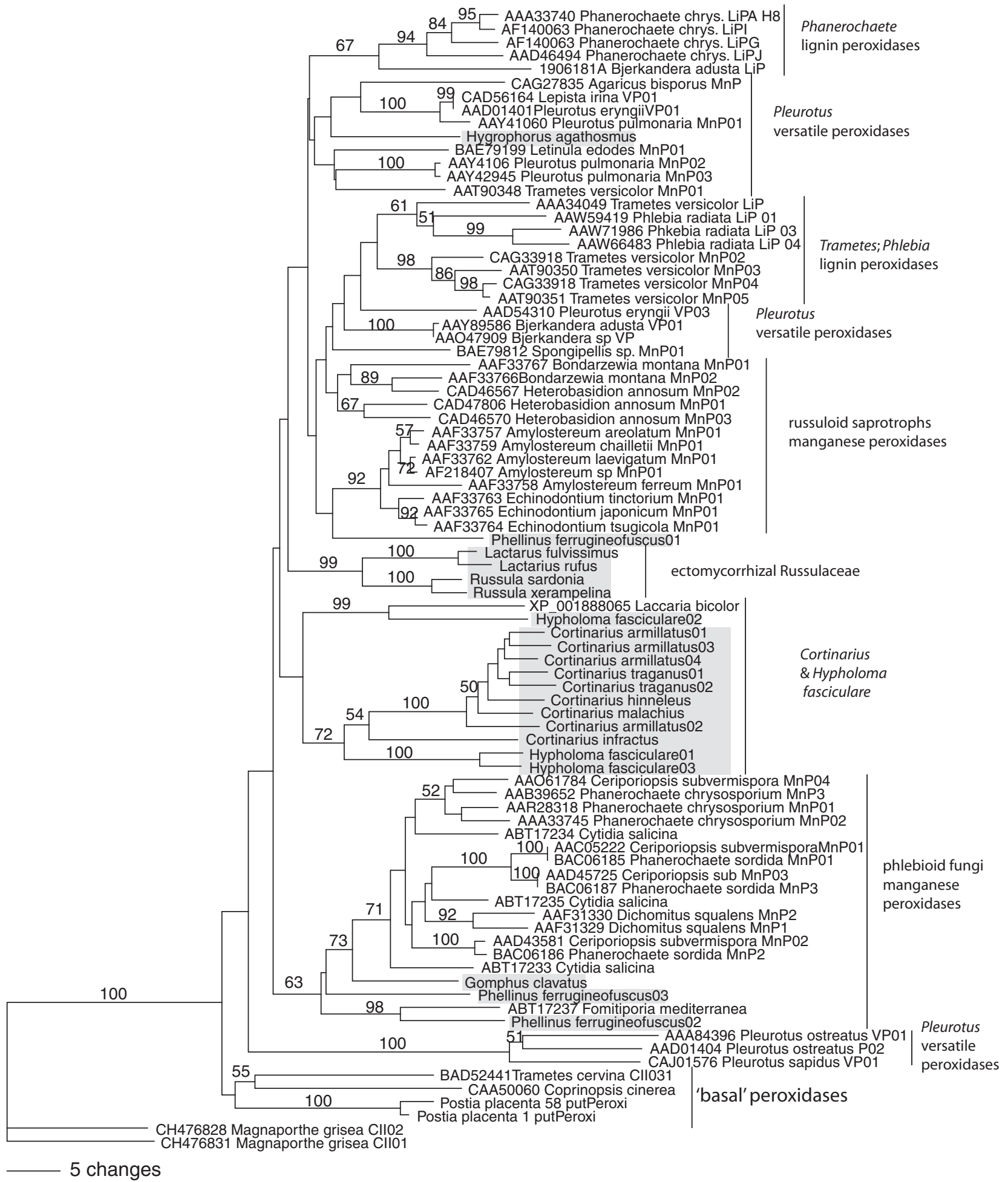

Figure 1 Phylogenetic analysis of novel and known ClassII peroxidases by neighbour joining. The analysis is based on an alignment of published sequences and newly obtained peroxidase sequences (indicated by gray frames). Numbers on branches indicate bootstrap support and the tree was rooted with two ascomycetous peroxidases sequences from Magnaporthe grisea.

to known peroxidase sequences. There are several variables that influence the success of PCR amplification, as each sample requires separate optimization of extraction and PCR conditions. Thus, amplification may fail due to insufficient optimiza- tion rather than absence of the target gene. Whether the template DNA was extracted from dried or fresh sporocarps or from culture material seems not to have had a major influence on amplification success. 
Even when PCR was successful, the lack of peroxidase genes among the sequenced amplicons does not imply that such genes do not exist. The primers we used were highly degenerated, mainly due to the presence of inosine. The low specificity was necessary to cover a wide variety of ClassII peroxidase genes and in order to obtain amplicons from phylogenetically distant taxa. In many cases, multiple bands were obtained, and after cloning between 8 and 36 (average 14), bacterial colonies were collected and between 1 and 21 selected clones (average 8) were sequenced. However, the possibility of missing peroxidase amplicons among a multitude of non-target amplicons remains. Perhaps more importantly, the presence of non-target template with higher primer affinity than the peroxidase genes may preclude amplification of the desired genes. In addition, introns within the reverse primer site are present in some previously studied $\mathrm{Mn}$ peroxidase-encoding genes, for example, in some polyporoid fungi, and may have also prevented amplification in other groups.

Most of the amplified peroxidase sequences were 395-572 bp long, corresponding to a protein sequence of about 130-140 amino acids after the removal of introns. Some amplicons, however, were considerably shorter; around $320 \mathrm{bp}$ corresponding to 89 amino acids. The shorter sequences resulted from binding of primer 2 to an alternative site (Figure 2) closer to the upstream primer and highly similar in sequence to the intended target binding site. Such short amplicons were obtained from the Russulaceae species as well as from $C$. infractus. From one of the $H$. fasciculare genes, both short and long amplicons were obtained, confirming the occurrence of two alternative binding sites for primer 2, highlighting the low specificity of the reverse primer in particular.

All the deduced protein sequences from this study (long amplicons) contained an amino acid (D175), which is essential for the oxidation of $\mathrm{Mn}^{2+}$ (RuizDuenas et al., 1999; Martinez, 2002). In contrast, the most important aromatic substrate-binding site (W164/W172), which is responsible for electron transfer during the direct oxidation of aromatic substrates by lignin and versatile peroxidases, was missing from all sequences obtained in this study (Figure 2). This suggests that the identified genes code for Mn-dependent peroxidases that bind $\mathrm{Mn}^{2+}$ as substrate and oxidize this to $\mathrm{Mn}^{3+}$. This $\mathrm{Mn}^{3+}$ in return oxidizes many different substrates (for example, lignin or humic substances) in the closer environment with a low degree of specificity. However, two additional amino acids essential for $\mathrm{Mn}^{2+}$ oxidation are not included in our amplified region. Thus, we cannot predict with certainty that the genes are fully functional manganese peroxidases. In Cortinarius, gene duplications seem to have occurred during evolution of the genus (Figure 1). However, a more resolved picture of gene evolution within the Cortinariaceae may be obtained with a better taxonomic representation.

Conservation of duplicated genes within gene families suggests that the genes are under strong selection pressure and contribute to the fitness of the organism (Lynch and Conery, 2000; Wapinski et al., 2007). Further studies of gene expression and regulation are necessary to confirm active roles and establish functions of ectomycorrhizal peroxidase genes.

Our results imply that ClassII peroxidase genes are present across a wider taxonomic and ecological range of homobasidiomycetes than previously known. We detected peroxidase sequences in five different ectomycorrhizal genera, including the species rich and ecologically important Cortinarius, Lactarius and Russula. These findings support the idea that ectomycorrhizal fungi have a capacity to oxidize and degrade polyphenolic compounds, such as lignin and humic acids.

Bending and Read (1996) proposed that polyphenol-degrading enzymes, produced by mycorrhizal fungi, may have an important role in the mobilization of nitrogen from acidic soils. In a boreal forest, ectomycorrhizal taxa dominated the fungal community within the humus layer, in which the C:N ratio increased with the age of organic matter. This suggests that humus nitrogen was removed at a higher rate than the carbon (Lindah et al., 2007). Enzymatic oxidation of polyphenolic compounds is a co-metabolic process that requires access to other, more labile carbon sources (Kirk and Farrell, 1987). Thus, in the boreal forest humus, host photoassimilates could be used to drive selective mobilization of humus nitrogen, mediated by ectomycorrhizal peroxidases. Recently, Talbot et al. (2008) also proposed a scenario where ectomycorrhizal fungi act as 'coincidental decomposers,' degrading soil organic matter in search for nutrients and thereby releasing sequestered soil carbon as a side effect. Furthermore, in a pot experiment, Dijkstra and Cheng (2007) showed that the presence of tree roots accelerated the loss of old soil carbon, so called a 'priming effect.' Thus, supported by the

Figure 2 Protein sequence alignment of all novel detected sequences (names marked gray) together with a few earlier published ones (LiP, lignin peroxidase; VP, versatile peroxidase; MnP, manganese peroxidase). The black shading indicates the primers (Primer 1, forward; GGADGS and Primer 2, reverse; PFDST). Gray-shaded residues are conserved sites, important for protein folding or catalytic function. Their functions according to Martinez (2002) are explained on the bottom: $A$, aromatic substrate oxidation; $B$, disulfide bridge; $C, \mathrm{Ca}^{2+}$-binding residue; $H$, heme pocket residue; $M, \mathrm{Mn}^{2+}$-binding residue. The abbreviation alt $P 2$ indicates the alternative binding site for the reverse primer 2 (light-gray background). Reference sequences were obtained from NCBI: Phanerochaete chrysosporium LiP H8: M37701; P. chrysosporium MnP1: M60672; Bjerkandera adusta VP01: DQ060037; Pleurotus eryngii VP01: AF007221; P. ostreatus VP: U21878; P. ostreatus MnP: AB04546; Dichomitus squalens MnP01: AF157474; D. squalens MnP02: AF157475. 
Phanerochaete chrys. LiP H8 Bjerkandera adusta VP01 Pleurotus ostreatus VP Pleurotus eryngii VP01 Phanerochaete chrys. MnP1 Dichomitus squalens_MnP2 Dichomitus squalens $\mathrm{MnP1}$ Pleurotus ostreatus MnP03 Phellinus ferrugineofuscus 01 Phellinus ferrugineofuscus03 Phellinus ferrugineofuscus 02 Hypholoma fasciculare01 Hypholoma_fasciculare02 Hypholoma_fasciculare03 Hygrophorus agathosmus Gomphus clavatus Cortinarius armillatus01 Cortinarius armillatus02 Cortinarius armillatus03 Cortinarius armillatus 04 Cortinarius hinneleus Cortinarius infractus Cortinarius malachius Cortinarius traganus01 Cortinarius traganus 02 Russula sardonia Russula xerampelina Lactarius rufus Lactarius fulvissimus
...$$
{ }_{5} \cdots|\cdots|
$$

15

25

35

$$
45
$$

55

GGADGSIMIFDDIETAFHPNIGLDEIVKLQKPFVQKHG VTPGDFIAFAGRVALSNCPGAPQMNFFT GGADGS IMIFDDIEPNFHANNGVDEI ISAQKPFVAKHN MTAGDFIQFAGAVGVSNCPGAPQLSFFL GGADGSVITFSDTEVNFPANLGIDEIVEAEKPFLARHN ISAGDLVHFAGTLAVTNCPGAPRIPFFL GGADGS IIAFDTIETNFPANAGIDEIVSAQKPFVAKHN ISAGDFIQFAGAVGVSNCPGGVRIPFFL GGADGSMLLFPTVEPNFSANNGIDDSVNNLIPFMQKHN TISAADLVQFAGAVALSNCPGAPRLEFLA GGADGSMLIFPTVEPAFFANLGIADSVNNLIPFLSQFP KISAGDLVQFAGAVAVGNCPGAPQLEFRA GGADGSMLLFPTVEPAFFANLGIADSVNNLIPFMSQFP NISPGDLVQFAGAVAITNCPGAPQLEFLA GGADGS IVTFDEIETAFHANGGIDDIVDAQKPFIARHN ISAGDFIQFAGAVGVSNCPGAPRLNFLL GGADGSIITFAKTETAYHANNGIDDIVDAQRPFVSKWN VTPGDFIQFAGAVGVSNCPGAPRLQFFT GGADGSIILFSDIETNFAANAGTDDGVDALAPELTRHN VSAGDLIQFASAVGLTNCPGAPRLQFLA GGADGSIMIFNNTELLDPANDGISDAVNNLKPLLMTHP VTAGDLIQFAGAVAVSNCPGAPQLEFLA GGADGSIATFNETELTFPANLGIDDVLDDLGPFILKHA NTVSPGDFIQLAGAVSLVQCPGAPRIPFFM GGADGSILASNSTELAFHANGG * DIFSQQNITVKNLNI ILSPGDF IHLAAAVGTANCPGAPRLEFMF GGADGSIATFNETELTFPANLGIDDILDEIGPFILKHT NTMTPGDFIQLAGALSLVQCPGAPRIPFFM GGADGSIIDFDTIETAYHANNGIES IVATQKRFIAKY D ISAGDF IQFAGAVGVSNCPGAPQLDFML GGADGSMLIFPDVEPNFHANLGISDSVDALTPFLQAHN TITAGDLIQFAAAVGITNCPGAARLEFLA GGADGSI I IFNATELLDPGNVGI DDVLGEISPFFFKHA AITPGDF IQFAGALSLTVCPGAPKVEFVI GGADGSIIIFNETELKDPGNIGIDDVLGQITPFFEKHA DAITPGDFIQFAGALSLTLCPGAPKVQFS I GGADGSIIIFNATEYLTPGNVGIDDVLGEESPFFFKHA DAITPGDFIQFAGALSLTLCPGAPKVQFVI GGADGSIIIFNATELLDPGNVGIDDVLGEESPFFFKHA DAITPGDFIQFAGALSLSVCPGAPRVQFVI GGADGSIIIFNATELLDPGNVGIDDVLDVISPFFFKHS NAITPGDFIQLAGALSLTVCPGAPKVEFVI $\sim$ GADGSI I IFNQTELMDPANNGI DDVLDQVGPFFQKTA SVLSPGDF IQLAGAVSLTQCPGAPQVKFLL GGADGSIIIFNATELLDPGNVGIDDVLSEISPFFFKHA AAITPGDFIQFAGALSLTVCPGAPQVKFDI GGADGSI I IFNATELLDPGNVGIDDVLGEISPFFFKHA DAISPGDFIQFAGALSLTVCPGAPKVKFS I GGADGSIIIFNATEFLDPGNVGIDDVLGEISPFFFKHA DAITPGDFIQLAGALSLTVCPGAPRVKFVI GGADGSIMIFEDIETQYPANGGIDDIVKAQAQFLLQFGG VISPGDFIQLAGAVGISNCPGAPRLQFLL GGADGSIMAFGDIEMQYPANGGIDDIVNAQAQFLSQFGG VISPGDF IQLAGAVGLSNCPGAPRLQFLL GGADGSIMTFSDIETQYTANGGLDDIVKMQERCLSECGCDGIVSPGDF IQLAGAVGVGNCPGAPRLRFLI

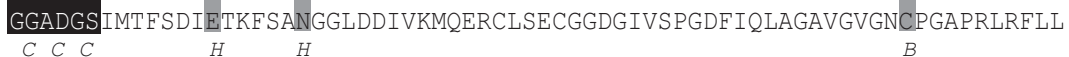

$\ldots|\ldots| \ldots|\ldots| \ldots|\ldots| \ldots|\ldots| \ldots|\ldots| \ldots|\ldots| \ldots|\ldots| \ldots|\ldots| \ldots \mid \ldots$

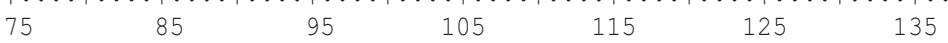
GRAPATQPAPDGLVPEPFHTVDQI INRVNDAGEFDELELVWMLS AHSVAAVNDVDPTVQGLPFDST GRPAATQPAPDGLVPEPFDSVTDILNRFADAGGFTTQEVVWLLA SHSIAAADHVDPTIPGSPFDST GRPPAKAASPIGLVPEPFDTITDILARMDDAG FVSVEVVWLLS AHSVAAADHVDETIPGTPFDST GRPDAVAASPDHLVPEPFDSVDS ILARMSDAG FSPVEVVWLLA SHSIAAADKVDPSIPGTPFDST GRPNKTIAAVDGLIPEPQDSVTKILQRFEDAGGFTPFEVVSLLA SHSVARADKVDQTIDAAPFDST GRPNATAPAIEGLIPEPQNNITEILERFDDAGGFSPFEVVSLLA SHTVARADHVDPTLDAAPFDST GRPNGTAPA IDGLIPEPQDS IDDILARFDDAGGFTPEEVVSLLA SHTVARADHVDPTLDAAPFDST GRPPATAASPNGLIPEPFDTVTDILARMGDAG FSPEEVVALLA SHSVAAADHVDETIPGTPFDST GRPDPLAPAPDLTLPEPYHTVDS ILARFGEVG FSADEVVALMA SHSVGAADHVDPTIPDTPFDST GRPNAT IPAGDGA IPQPQDSVDS ILSRFADAG FSSAEVIHLLA SHTVARSDTLVPGHEAVPFDST GRPNATFPAQQGTVPLPRDSSSKILARMGDAG LSPQDTINLLV SHTVARSDTLVPNHQAVPFDST GRAQPKAASP PNLVPQPTDSITTILERFSSVG FSPAEVVAVV GGSHSVAGADDVVPNFQGIPFDST GRPPPLAAAPDLTVPEPTDSVTKILARFADAG FAPAEAVALLS SHTIAAADVVDPTIPGTPFDST GRAQPKAASPPNLVPQPFDSVAS IVQRFNEVG FTTPEEIVSVIGGSHSVAGADDVVPGLQGLPFDST GRPAATAASPDFLVPEPFDSVDKILDRFSDAG FSPAEVVALLA SHTIAGADHVDPS IPGTPFDST GRPNATAPAPDGLVPEPQDSLDKIFARMEDGGGFTPDELIALLA SHTIARSDHIDPAIQQVPFDST GRPQPKGPAPDF IVPQPTNTTDQLLTAFANVG FSPAELIALLA SHTAAGADDFSPPLQGVPFDST GRPPPIAPAPDFIVPQPVNTTDELLTAFAAVD FSPEELVALLT SHTVAGADDFAP PLQGVPFDST GRPQPKGPAPDF IVPQPINTTDELLTAFANVD FSPEEFIALLA SHTAAGADDFSPPLQGVPFDST GRPQPKEPAPDFIVPQPVNTTDELLTAFANVD FSPAEFIALLA SHTAAGADDFSP PLQGVPFDST GRPAPKGPAPDF I IPQPVNTTDELLAAFAAVG FSPAELVALLA SHTAAGADDFSPPLKGIPFDST GRPPPVAAASAGLVPEPFDST GRPPPVAPAPDFIVPQPTNTTSQLIAAFANIC LSPAELVALLA PHTAAGADDFAPPLQGVPFDST GRPAPLGPAPDF IVPQPVNTTDELLAAFAAVD FSPEELIALLA SHTAAGADDFSP PLQGVPFDST GRPAPVEPAPPFIVPQPVNTTDELLAAFAVVD FSPAELVALLA SHSAAGADDFSPPLAGVPFDST GRPNATAPAPDHTIPAPFDST GRPNATAPAPDHTIPAPEDST GRPNATAPAPENMVPAPEDST
GRPNATAPAPDNMVPAPEDST $~$ alt $\mathrm{P} 2$ A HC $\quad M$ $M$ $\mathrm{HCC}$ 
results of this study, the expression of peroxidase enzymes by mycorrhizal fungi may constitute a link between photosynthesis and the degradation of recalcitrant soil organic matter.

\section{Acknowledgements}

We gratefully acknowledge the Swedish University of Agricultural Sciences for financial support of the project. Further, we thank Katarina Ihrmark for practical help and advice during the laboratory work, Rimvydas Vasaitis for kindly providing the culture of Phellinus ferrugineofuscus and Karina Clemmensen and Petra Fransson for critical reading of the paper.

\section{References}

Aerts R. (1995). The advantages of being evergreen. Trends Ecol Evol 10: 402-407.

Altschul SF, Madden TL, Schaffer AA, Zhang JH, Zhang Z, Miller W et al. (1997). Gapped BLAST and PSI-BLAST: a new generation of protein database search programs. Nucleic Acids Res 25: 3389-3402.

Baldrian P. (2006). Fungal laccases-occurrence and properties. FEMS Microbio Rev 30: 215-242.

Bao W, Omalley DM, Whettn R, Sederoff RR. (1993). A laccase associated with lignification in loblolly-pine xylem. Science 260: 672-674.

Bending GD, Read DJ. (1996). Nitrogen mobilization from protein polyphenol complex by ericoid and ectomycorrhizal fungi. Soil Biol Biochem 28: 1603-1612.

Bending GD, Read DJ. (1997). Lignin and soluble phenolic degradation by ectomycorrhizal and ericoid mycorrhizal fungi. Mycol Res 101: 1348-1354.

Binder M, Hibbet DS, Larsson KH, Larsson E, Langer E, Langer G. (2005). The phylogenetic distribution of resupinate forms across the major clades of mushroom-forming fungi (Homobasidiomycetes). System Biodivers 3: 113-157.

Chambers SM, Burke RM, Brooks PR, Cairney JWG. (1999). Molecular and biochemical evidence for manganesedependent peroxidase activity in Tylospora fibrillosa. Mycol Res 103: 1098-1102.

Chenna R, Sugawara H, Koike T, Lopez R, Gibson TJ, Higgins DG et al. (2003). Multiple sequence alignment with the Clustal series of programs. Nucleic Acids Res 31: 3497-3500.

Dijkstra FA, Cheng WX. (2007). Interactions between soil and tree roots accelerate long-term soil carbon decomposition. Ecol Lett 10: 1046-1053.

Haselwandter K, Bobleter O, Read DJ. (1990). Degradation of C-14 labeled lignin and dehydropolymer of coniferyl alcohol by ericoid and ectomycorrhizal fungi. Arch Microbiol 153: 352-354.

Hatakka A. (1994). Ligin-modifying enzymes from selected white-rot fungi-production and role in lignin degradation. FEMS Microbiol Rev 13: 125-135.

Hibbett DS, Gilbert LB, Donoghue MJ. (2000). Evolutionary instability of ectomycorrhizal symbioses in basidiomycetes. Nature 407: 506-508.

Kirk TD, Farrell RL. (1987). Enzymatic combustion-the microbial degradation of lignin. Ann Rev Microbiol 41: 465-505.
Knudsen H, Versterholt J. (2008). Funga Nordica. Nordsvamp. Copenhagen, Denmark.

Koide RT, Sharda JN, Herr JR, Malcom GM. (2008). Ectomycorrhizal fungi and the biotrophy-saprotrophy continuum. New Phytol 178: 230-233.

Lindahl BD, Ihrmark K, Boberg J, Trumboe SE, Hogberg P, Stenlid J et al. (2007). Spatial separation of litter decomposition and mycorrhizal nitrogen uptake in a boreal forest. New Phytol 173: 611-620.

Lindahl BD, Taylor AFS. (2004). Occurrence of $N$ acetylhexosaminidase-encoding genes in ectomycorrhizal basidiomycetes. New Phytol 164: 193-199.

Lindahl BD, Taylor AFS, Finlay RD. (2002). Defining nutritional constraints on carbon cycling in boreal forests-towards a less 'phytocentric' perspective. Plant Soil 242: 123-135.

Lynch M, Conery JS. (2000). The evolutionary fate and consequences of duplicate genes. Science 290: 1151-1155.

Maijala P, Harrington TC, Raudaskoski M. (2003). A peroxidase gene family and gene trees in Heterobasidion and related genera. Mycologia 95: 209-211.

Martin F, Aerts A, Ahren D, Brun A, Danchin EGJ, Duchaussoy F et al. (2008). The genome of Laccaria bicolor provides insights into mycorrhizal symbiosis. Nature 452: 88-92, U7.

Martinez AT. (2002). Molecular biology and structurefunction of lignin-degrading heme peroxidases. Enzyme Microb Technol 30: 425-444.

Morgenstern I, Klopman S, Hibbett DS. (2008). Molecular evolution and diversity of lignin degrading heme peroxidases in the agaricomycetes. J Mol Evol 66: 243-257.

Myneni RB, Dong J, Tucker CJ, Kaufmann RK, Kauppi PE, Liski J et al. (2001). A large carbon sink in the woody biomass of Northern forests. Proc Natl Acad Sci USA 98: 14784-14789.

Northup RR, Yu ZS, Dahlgren RA, Vogt KA. (1995). Polyphenol control of nitrogen release from pine litter. Nature 377: 227-229.

Nygren CMR, Eberhardt U, Karlsson M, Parrent JL, Lindahl BD, Taylor AFS. (2008). Growth on nitrate and occurrence of nitrate reductase-encoding genes in a phylogenetically diverse range of ectomycorrhizal fungi. New Phytol 180: 875-889.

Passardi F, Bakalovic N, Teixeira FK, Margis-Pinheiro M, Penel C, Dunand C. (2007a). Prokaryotic origins of the non-animal peroxidase superfamily and organellemediated transmission to eukaryotes. Genomics $\mathbf{8 9}$ : $567-579$.

Passardi F, Theiler G, Zamocky M, Cosio C, Rouhier N, Teixeira F et al. (2007b). PeroxiBase: the peroxidase database. Phytochemistry 68: 1605-1611.

Pérez-Boada M, Ruiz-Duenas FJ, Pogni R, Basosi R, Choinowski T, Martinez MJ et al. (2005). Versatile peroxidase oxidation of high redox potential aromatic compounds: site-directed mutagenesis, spectroscopic and crystallographic investigation of three long-ranged electron transfer pathways. J Mol Biol 354: 385-402.

Rayner ADM, Boddy L, Dowson CG. (1987). Genetic interactions and developmental versatility during establishment of decomposer basidiomycetes in wood and tree litter. In: Fletcher M, Gray TRG, Jones JG (eds). Symposium of the Society for General Microbiology, 41. Ecology of Microbial Communities. Cambridge University Press: New York, USA, Cambridge, UK. 
Read DJ. (1991). Mycorrhizas in ecosystems. Experientia 47: 376-391.

Robinson JM. (1996). Atmospheric bulk chemistry and evolutionary megasymbiosis. Chemosphere 33: 1641-1653.

Ruiz-Duenas FJ, Martinez MJ, Martinez AT. (1999). Molecular characterization of a novel peroxidase isolated from the ligninolytic fungus Pleurotus eryngii. Mol Microbiol 31: 223-235.

Sinsabaugh RL. (2005). Fungal enzymes at the community scale. In: Dighton J, White JF, Oudemans P (eds). The Fungal Community. Its Organization and Role in the Ecosystem, 3rd edn. Taylor \& Francis: Boca Raton, FL. pp 349-360.

Steffen KT, Hatakka A, Hofrichter M. (2002). Degradation of humic acids by the litter-decomposing basidiomy- cetes Collybia dryophila. Appl Environ Microbiol 68: 3442-3448.

Swofford DL. (2003). PAUP*. Phylogenetic Analysis Using Parsimony ( ${ }^{*}$ and Other Methods). Sinaur Associates: Sunderland, MA.

Talbot JM, Allison SD, Treseder KK. (2008). Decomposers in disguise: mycorrhizal fungi as regulators of soil $\mathrm{C}$ dynamics in ecosystems under global change. Funct Ecol 22: 955-963.

Trojanowski J, Haider K, Huttermann A. (1984). Decomposition of C-14 labeled lignin, holocellulose and lignocellulose by mycorrhizal fungi. Arch Microbiol 139: 202-206.

Wapinski I, Pfeffer A, Friedman N, Regev A. (2007). Natural history and evolutionary principles of gene duplication in fungi. Nature 449: 54-61.

Supplementary Information accompanies the paper on The ISME Journal website (http://www.nature.com/ismej) 